\title{
A systematic literature review on Entrepreneurial Intentions: Citation, Thematic Analyses, and Research Agenda
}

\author{
Francisco Liñán ${ }^{1}$ \\ University of Seville \\ Dept. Applied Economics, Av. Ramon y Cajal,1. 41018-Seville, Spain
}

\author{
Alain Fayolle \\ EMLYON Business School \\ 23 Av. Guy de Collongues, BP 174, 69132 Ecully Cedex, France
}

\begin{abstract}
Entrepreneurial intention is a rapidly evolving field of research. A growing number of studies use entrepreneurial intention as a powerful theoretical framework. However, a substantial part of this research lacks systematization and categorization, and there seems to be a tendency to start anew with every study. Therefore, there is a need to take stock of current knowledge in this field. In this sense, this paper carries out a review of the literature on entrepreneurial intentions. A total of 409 papers addressing entrepreneurial intention, published between 2004 and 2013 (inclusive), have been analyzed.

The purpose and contribution of this paper is to offer a clearer picture of the sub-fields in entrepreneurial intention research, by concentrating on two aspects. Firstly, it reviews recent research by means of a citation analysis to categorize the main areas of specialization currently attracting the attention of the academic community. Secondly, a thematic analysis is carried out to identify the specific themes being researched within each category. Despite the large number of publications and their diversity, the present study identifies five main research areas, plus an additional sixth category for a number of new research papers that cannot be easily classified into the five areas. Within those categories, up to twenty-five different themes are recognized. A number of research gaps are singled out within each of these areas of specialization, in order to induce new ways and perspectives in the entrepreneurial intention field of research that may be fruitful in filling these gaps.
\end{abstract}

Keywords: entrepreneurial intention, literature review, citation analysis, thematic analysis, research gaps, research agenda, new research perspectives

\section{Introduction}

The literature on entrepreneurial intentions (EI) has rapidly grown since the publishing of the seminal works by Shapero some 30 years ago (Shapero 1984; Shapero and Sokol 1982). More and more papers are being written in the field. Furthermore, the integration of theories from the

\footnotetext{
${ }^{1}$ Corresponding author: flinan@us.es, Tel.: +34.954554487; Fax: +34.954551636
} 
area of social psychology has contributed towards increasing the theoretical strength and methodological rigor of contributions (Ajzen 1991; Bandura 1982).

Since the early nineties, we have seen an explosion of research using entrepreneurial intention models as a framework, thereby confirming the applicability of the concept in various settings. Nevertheless, despite the existence of alternative models, there is some evidence of the compatibility of these intention-based models (Boyd and Vozikis 1994; Krueger et al. 2000). Additionally, with the publication of an increasing number of studies based on the concept of EI, new applications, mismatches and specifications have emerged (Carsrud and Brännback 2011; Krueger 2007, 2009; Krueger and Day 2010). The vast majority of this research lacks systematization and categorization, with a tendency to start anew with every study. There is therefore a risk of the field stagnating and lacking robustness (Fayolle and Liñán 2014). There is a considerable need to provide some ordering and systematization in this research to contribute towards further advancement in the field. In particular, this would help to identify not only the main themes in the literature, but also the existing gaps and new relevant lines of research.

Consequently, the purpose of this paper is to offer a clearer picture of the sub-fields in EI research. Firstly, the authors review recent influential contributions in the field, and identify the most important areas of specialization within it. Secondly, the present study serves to recognize a number of research themes within each of these areas of specialization, in order to induce new ways and perspectives in the EI field of research that may be fruitful in filling the existing gaps. To achieve its aims, this study follows a citation analysis procedure to identify influential papers that serve to define the main categories of research in the field. This framework is then used in the classification of contributions made since 2004 in the area of entrepreneurial intentions into main themes within each category.

\section{The entrepreneurial intention research area}

When examining the literature on EI, two distinct strands of research emerge. The first comes from social psychology, with a view to analyzing behaviors in general and shedding light on the mental process leading from attitudes and beliefs to effective action. Two major contributions from the discipline are especially relevant for the study of EI: that of Ajzen and Fishbein (1980) and of Bandura (1997). A further development, Ajzen's (1991) Theory of Planned Behavior (TPB), has become one of the most widely-used theories in social psychology in general (Ajzen 2012). The second strand is specific to the field of entrepreneurship (Shapero 1984; Shapero and Sokol 1982; Bird 1988).

The convergence of both these strands of the literature owes much to some specific contributions which made a very convincing case for the adoption of tools and theories from psychology in entrepreneurship (Shaver and Scott 1991). The paper by Krueger and Carsrud (1993) is probably responsible for making the TPB the "reference" theory in EI research. Krueger and Brazeal (1994) tried to reconcile it with Shapero's (1984) theory of the entrepreneurial event (EEM). Boyd and Vozikis (1994), in turn, develop Bird's (1988) model and make it converge with the TPB model, although this was not their specific objective. Soon after that, two well-known contributions by Kolvereid (1996a, 1996b) served to definitely establish the applicability and usefulness of the TPB model in entrepreneurship. 
From then on, research in EI has expanded widely, focusing on many different nuances. Therefore, it seems justified to take stock of recent research, in an effort to identify the main sub-areas of research within the field of EI. The boundaries of the field are sometimes difficult to establish. For instance, some papers study intentions at the firm level (Xiao et al. 2013). This would be closer to the concept of entrepreneurial orientation - EO - (Covin and Slevin 1989; Kraus et al. 2012; Rigtering et al. 2014) which is an organizational characteristic. In turn, the concept of EI is studied here at the individual level only (Krueger et al. 2000; Werner et al. 2014).

\section{Methodology}

Research in EI has considerably expanded; considering it as a homogeneous area of study is no longer possible. In order to analyze the most recent literature on EI and identify main areas of specialization, the authors have performed a systematic search of the literature (Gundolf and Filser 2013; Kraus, et al. 2014; Xi et al. 2013). This is based on the recommendations from the methodological and entrepreneurship literature to ensure it being systematic, transparent and thus replicable (Armitage and Keeble-Allen 2008; Lourenço and Jones 2006; Pittaway and Cope 2007; Tranfield et al. 2003). Only journal articles have been included in this search, since they are considered as validated knowledge (Podsakoff et al. 2005). In contrast, due to the variability in the peer review process and their more restricted availability, books, chapters and conference papers have been excluded (Jones et al. 2011).

Initially, the Scopus database was searched for journal articles published from 2004 to 2013 (inclusive) containing both the keywords "entrep*" and "intent*", as is common in similar research in the field (Cornelius et al. 2006). The selection of this database is due to its wider coverage of journals. This yielded 514 papers. Additionally, the same search was run in other highly-used databases: Web of Science (Social Science Citation Index), ABI-Inform/ProQuest, and Science Direct. After integrating all the results and eliminating duplicate documents, a total of 732 papers were initially identified.

All 732 abstracts were read by one of the authors to ensure that the paper really analyzes EI. When a doubt arose, the whole paper was read for this to be confirmed. This process found 323 articles focusing on a different topic and these were therefore eliminated. The analysis hereinafter includes the remaining 409 papers. The full list of papers is not included here due to space constraints, but it is available from the authors upon request.

As a starting point, a citation analysis was conducted to identify the most influential publications within this period (Gundolf and Filser 2013). Citations reflect the interconnection between researchers and the conjunctions between the different scientific conceptions (Kraus et al. 2014). The frequency of citations is an indication of their importance and the qualitative value of the document (Xi et al. 2013). A regularly cited publication should be considered as conveying important scientific knowledge that is used as a foundation for further elaboration (Acedo and Casillas 2005; Casillas and Acedo 2007). Therefore, following the approach adopted by Gundolf and Filser (2013), we determined the most-cited publications within our data set of 409 papers.

The categories which emerged from the most-cited publications were used as a reference for the thematic analysis of the remaining papers in our data set. Following Ryan and Bernard (2003), 
themes are taken to represent the fundamental concepts that describe the subject matter of each author's article. Thus, themes and sub-themes represent the core ideas, arguments and conceptual linking of expressions on which an article's research questions, constructs, concepts and/or measurements are based (Thorpe et al. 2005). Drawing on these principles, themes were inductively derived from our holistic understanding of each article (Jones et al. 2011).

\section{Citation analysis}

From the analysis of cross-citations among the 409 papers in our sample, a total of 24 influential papers were identified. These have received the highest number of citations from papers in the sample. These 24 most-cited research works were analyzed and classified into topic clusters based on content similarities (Kraus et al. 2014; Xi et al. 2013). To this end, both authors carefully read all 24 papers independently to identify the main topic areas being addressed. This resulted in the identification of five categories of papers, with no conflict emerging between the classifications made by each author. The five categories are described below. Table 1 presents the classification of these 24 highly-influential papers into the topic clusters. As expected, the vast majority of them (20 papers) were published in the first half of the period under study (2004-2008), while only three papers were published in 2009 and one in 2010. Thus, these latter papers have been relatively quick in gaining an acceptance and a reputation in the EI academic community. Figure 1 offers a graphical representation of the five categories.

\section{INSERT TABLE 1 AROUND HERE \\ INSERT FIGURE 1 AROUND HERE}

\subsection{Group 1: Core model, methodological and theoretical issues (5 papers).}

These papers analyze the central elements of the model and address theoretical or methodological issues affecting this model. Thus, Zhao et al. (2005) analyze the specific configuration of self-efficacy as a motivational antecedent of EI. They find that it fully mediates the influence of a number of background variables on intention. Hmieleski and Corbett (2006), in turn, propose proclivity for improvisation as an additional explanatory variable in the EI model. Van Gelderen et al. (2008) carry out a general test of the theory of planned behavior for EIs. Finally, two additional papers focus on methodological issues, developing and validating either a complete questionnaire - entrepreneurial intention questionnaire (EIQ) - to measure TPB constructs (Liñán and Chen 2009) or specifically an EI scale (Thompson 2009).

\subsection{Group 2. Influence of personal-level variables (9 papers):}

This category is the largest, and includes papers studying the effect of personal traits, psychological variables, demographics or experience on EI. The role of some psychological variables, such as risk-perception (Segal et al. 2005) and career anchors (Lee and Wong 2004), in explaining the EI is analyzed. Another group of four papers focuses on background variables and their influence on intention. Thus, Carr and Sequeira (2007) rigorously test the influence of 
prior family exposure to entrepreneurship, while Gird and Bagraim (2008) confirm this result for the more general concept of prior entrepreneurial exposure. The influence of university studies is considered by Guerrero et al. (2008), while Liñán and Santos (2007) focus on the role of social capital. The three remaining papers focus on gender issues. The oldest contribution is that of Wilson et al. (2007), who find entrepreneurship education to have a greater effect on women's self-efficacy and, through this, on intentions. Gupta and collaborators center on gender stereotypes in entrepreneurship (Gupta et al. 2009), while the explicit activation of these stereotypes modifies the reported intention level of the participants (Gupta et al. 2008).

\subsection{Group 3. Entrepreneurship education and intentions (4 papers):}

These papers evaluate education programs or link them with intention. Frank and Lüthje (2004) find that German-speaking university students exhibit lower intentions than MIT counterparts and attribute this difference to entrepreneurship education. Pittaway and Cope (2007) carry out a systematic literature review of the entrepreneurship education literature and find that, generally speaking, it has positive results on the EI of the participants. Finally, the remaining papers carry out rigorous evaluations of entrepreneurship education programs (EEP) - at least including preand post-measures to assess impact - either in science and engineering students (Souitaris et al. 2007) or only in engineering students (Fayolle et al. 2006).

\subsection{Group 4. The role of context and institutions (4 papers):}

These papers focus on the influence of regional, cultural or institutional environments on the configuration of EIs. To this end, these papers compare samples from different countries to try to find context-related differences in the participants' intentions: Kristiansen and Indarti (2004) compare Indonesian and Norwegian students; Veciana et al. (2005) compare samples from Spain and Puerto Rico; De Pillis and Reardon (2007) analyze samples from Ireland and the USA. Finally, the most recent paper is more ambitious, since it compares 12 countries (Engle et al. 2010).

\subsection{Group 5. The entrepreneurial process and the intention-behavior link (2 papers):}

Finally, there are two papers specifically focusing on entrepreneurship as a process, and going beyond EI to predict actual behavior. Kolvereid and Isaksen (2006) carry out a longitudinal study on Norwegian nascent entrepreneurs to confirm that intention predicts behavior. Nabi et al. (2006), in turn, review the literature on the transition from student to starting up and identify several gaps that need to be addressed.

\section{Thematic analysis}

The thematic analysis took the categories resulting from the citation analysis as a starting point. All 409 papers were classified independently by each author into the five groups and themes within each group, and the classifications were compared. The resulting themes were highly compatible. Any discrepancy was discussed and solved by agreement and some minor changes 
were made to integrate these discrepancies. In the next step, the classification of each paper was compared, and a high degree of coincidence emerged. The allocation of a total of 67 papers presented some kind of disagreement between the two authors. After some discussion, they were reclassified or, alternatively, included in a new category (labelled as "new research areas"). In the case of papers addressing topics included in different categories, a decision was made to classify the papers into the category that was more closely aligned with the stated aim of the paper. If more than one aim was proposed, the most relevant result was chosen as a criterion for classification.

Within each category, several themes were identified, as shown in Figure 2. The number of papers in each category roughly follows the distribution of the most-cited papers in the citation analysis, with group 2 being the largest (148 papers) and group 5 being substantially less represented (39 papers). The remaining groups (1,3 and 4) include a similar number of papers each. Finally, the sixth category includes only 17 papers.

Table 2 presents the distribution of papers by category and by year. As the table shows, no obvious pattern emerges when comparing the year of publication and the research category. The evolution of the groups, though, implies an increase in the overall number of papers in the field, which has especially accelerated in the last few years. This means that, far from being an outdated area of research, its interest is rapidly increasing. In particular, it is after 2010 that a number of papers have been published addressing new areas of research. These cannot be classified in any of the previous categories. Therefore, they have been included in a new group (labelled "new research areas"). The thematic patterns characterizing these papers are now described.

\section{INSERT FIGURE 2 AROUND HERE}

\section{INSERT TABLE 2 AROUND HERE}

\subsection{Main themes in the core model, methodology, and theory category}

Most research in this category focuses on testing the most general specifications of EI models, concentrating mainly on the start-up intention. Nevertheless, some others focus on different types of intention (growth intention, intention to internationalize, intention to exit, and so on). Another subset of papers presents and/or tests new theoretical formulations different from the traditional TPB (Ajzen 1991) or EEM (Shapero 1982). Finally, we find three smaller themes within this first category: the inclusion of additional variables in the model; the detailed analysis of the specific configuration of the motivational antecedents of intentions; and the focus on methodology.

General test of the theory (23 papers). These papers predominantly test either the TPB or the EEM, using different samples, such as university students (e.g., van Gelderen et al. 2008), secondary school students (do Paço et al. 2011) or the general population (Drnovsek and Erikson 2005). These samples come from very different countries, including those which are developed (Germany, France, Spain, Portugal), in transition (Romania, Ukraine) and developing (Malaysia, China, Tunisia, Ethiopia, Afghanistan, Peru). The most widely used model is the TPB (e.g., Pihie 2009; Tegtmeier 2012), followed by the EEM (e.g., Lo and Wang 2007). 
Additionally, there are four papers comparing and/or integrating both models (Drnovsek and Erikson 2005; Jakopec et al. 2013; Salhi and Boujelbene 2013; Solesvik et al. 2012). In practice, they are sometimes integrated de facto, by using perceived desirability and feasibility as substitutes for personal attitude and behavioral control, but also by including a measure of the social valuation of entrepreneurship instead of the propensity to act. This is the case of Lanero et al. (2011) and Loras and Vizcaino (2013). The studies in this theme overwhelmingly confirm the applicability of intention models to entrepreneurship.

Specific intentions (18 papers). The logic behind intention models may be applied to any planned behavior, not only to starting up. In this sense, since entrepreneurship involves several steps, some papers have studied alternative entrepreneurial-process behaviors. The first attempts focus on obvious subsequent steps: the intention to grow (Kozan et al. 2006) and the intention to exit (Brigham et al. 2007). More recently, the intention to internationalize (e.g., Sommer and Haug 2011) and corporate EI (e.g., Fini et al. 2012) have also attracted attention. Another group of papers compare alternative EIs. Thus, Douglas (2013) finds differences in the attitudinal antecedents for growth versus independence intentions. Similarly, Carey et al. (2010) and Prabhu et al. (2012) compare the determinants of the intention to start various types of ventures (life-style, general, and high-growth). Again, as in the previous theme, intention models hold satisfactorily, although certain differences remain in the relative importance of the motivational antecedents, in the explanatory capacity, and in some additional variables contributing towards the explanation of each specific intention.

New theoretical framework (9). Under this theme, papers considering alternative models or substantial modifications of the established models are grouped together. Some proposals are closer to traditional intention models, such as expectancy theory (Renko et al. 2012) or social cognitive career theory (Hechavarria et al. 2012). Quan (2012) proposes a distinction between impulsive and deliberate EIs, each of which has different explanatory variables. Gartner (2010), in turn, proposes the intention/action/circumstance condition (IACC) as a new path to study entrepreneurship. Devonish et al. (2010) proposed a revised model, but their results showed the superiority of the conventional intention model. Overall, most of these new theoretical frameworks revealed themselves as potentially useful, although there is a need for further comparison and integration between the different models.

Additional variables (5). Since intention models typically explain $40 \%$ to $60 \%$ of the variance in EIs, some studies have proposed additional variables to be included in intention models. Thus, Hmieleski and Corbett (2006) incorporated proclivity for improvisation, and found it to be highly influential. More comprehensively, Hayton and Cholakova's (2012) theoretical paper argues in favor of the inclusion of affect, deriving testable propositions. The remaining papers are empirical. In particular, Tumasjan et al. (2013) test the contribution of temporal distance. This very interestingly adds a dynamic element to the intention model and helps explain a number of inconsistencies in previous research results.

Configuration of motivational antecedents (7). Traditional models in this field assume explanatory variables to directly and independently explain EIs. However, the authors in this theme have investigated alternative configurations, from among which three main categories can be highlighted. Mediation is analyzed by Zhao et al. (2005) in the case of self-efficacy, and by Nasurdin et al. (2009) with regards to desirability. Using a different focus, De Clercq et al. (2013) study how the influence of perceived ability and attractiveness on intention is moderated 
by learning orientation and passion for work. Fitzsimmons and Douglas (2011), in turn, focus on the interaction between desirability and feasibility.

Methodology (3). The three papers in this theme focus on concept definition and scale development. Two of these papers are more limited in scope in that they build and test either a multi-dimensional entrepreneurial self-efficacy instrument (McGee et al. 2009), or an EI scale (Thompson 2009). Liñán and Chen (2009), in turn, develop a complete EIQ which is then crossculturally tested in two clearly differentiated samples.

\subsubsection{Discussion}

Based on the different themes making up this "core model" category, we concur with previous works (Shook et al. 2003; Krueger 2009) in that key definitional challenges remain. There is room to integrate additional models, such as social cognitive career theory (SCCT) or expectancy theory, into the EI field of research. The connection between intent and other decision-making theories and models may also be explored (Krueger 2009). Thus, theoretical models of the entrepreneurial process that are integrative and more sophisticated may be developed, that link intention-based models with the prospect theory (Kahneman and Tversky 1979) or the effectuation theory (Sarasvathy 2001).

Similarly, additional variables and alternative - more complex -- configurations of motivational antecedents also deserve further attention to better understand the cognitive process leading to the start-up decision. There is also a need to investigate intention in a wide range of entrepreneurial situations by trying to capture and document, for example, corporate entrepreneurship intention, intention to exit, or intention to internationalize.

Finally, at the methodological level, the few attempts at developing research instruments (valid as they are) are insufficient. It is necessary to encourage research using samples of would-be entrepreneurs or nascent entrepreneurs. Following the suggestion by Shook et al. (2003), the authors also encourage researchers to triangulate their findings using multi-method studies.

\subsection{Main themes in the personal-level variables and entrepreneurial intention category}

This category includes the largest number of papers (148), and the diversity of the research is substantial. Thus, nearly half of these papers focus on the personality and psychology factors of the individuals under study, and how they affect intention. A second theme relates to the background and demographic factors that may also affect intention. However, given the great deal of attention paid to gender issues, we have separated this topic as a theme of its own. Finally, there are two very specific sub-sets of papers focusing on distinctive themes: specific subsamples, and perceived barriers.

Personality/psychology factors (72 papers). Despite some criticisms in the past, personality traits continue to attract considerable attention. Numerous paradigmatic studies in our sample analyze the influence of the big five personality traits on EIs (e.g., Zhao et al. 2010; Saeed et al. 2013). In this respect, Brandstätter (2011) presents the results of five meta-analyses, thereby confirming this relationship. Additionally, other, more specific, personality traits have been studied, such as risk perceptions (e.g., Segal et al. 2005; Nabi and Liñán 2013), locus of control (e.g., Zellweger et al. 2011), innovativeness (e.g., Ahmed et al. 2010), or even narcissism (Mathieu and St-Jean 2013). Other relatively stable psychological factors, such as cognitive- 
styles (e.g., Kickul et al. 2010) or career anchors (Lee and Wong 2004), are also found to affect intentions. On the other hand, there are some abilities or capacities that may be developed, such as creativity (e.g., Zampetakis et al. 2011), or emotional intelligence (e.g., Zampetakis et al. 2009). Again, they are both found to be positively related to EIs. Finally, personal values have also received some attention as possibly influencing attitudes and intention (Watchravesringkan et al. 2013). In general, therefore, the papers on this theme evidence the complexities inherent in personality and cognition, with many different types of variables affecting the way people see, interpret and react to reality.

Background factors (35). These papers analyze the role of several situational influences on the individuals' EI, including elements such as family background, education and experience. In the first case, the parents' occupation (Bhandari 2012) or the family business background (Hadjimanolis and Poutziouris 2011) are considered. Educational background is also relevant (Guerrero et al. 2008; Wu and Wu 2008), as is experience (Gird and Bagraim 2008). However, it is the influence of role models that attracts the greatest attention. In this respect, family role models seem to be more prominent (e.g., Carr and Sequeira 2007), but other models also exert a positive effect (e.g., Bosma et al. 2012; Radu and Loué 2008). Social capital, as an indication of the characteristics of the social network, is also a major background factor affecting intention (Liñán and Santos 2007).

Gender issues (30). Gender differences in EI probably constitute the most frequent single research topic in our sample. Males are found to exhibit a more positive attitude towards entrepreneurship and a higher EI (Strobl et al. 2012), as well as a more positive perceived feasibility (Dabic et al. 2012). Nevertheless, these results need further explanation. The association of entrepreneurship with a male gender stereotype seems to explain part of this difference (Gupta et al. 2008; Gupta et al. 2009). On the other hand, the effect of role models on self-efficacy is stronger for women (BarNir et al. 2011), as is the effect of entrepreneurship education (Wilson et al. 2007). Additionally, Haus et al. (2013) conclude that women transform their intentions into action to a much lesser extent than do men. In this regard, women tend to perceive different barriers to entrepreneurship (Shinnar et al. 2012). Finally, gender stereotypes (both implicit and explicit) also impact on women's high-growth EI (Sweida and Reichard 2013).

Specific subsamples (8). This theme corresponds to papers focusing on particular subgroups of the population, since they are supposed to present some peculiar characteristics. Two age groups received special attention: secondary school students who have limited experience (e.g., Marques et al. 2012); and members of the ageing population, who have much greater experience (Tornikoski and Kautonen 2009). The remaining papers focus on Dutch farmers (Bergevoet et al. 2004) or indigenous Turkish entrepreneurs (Uygun and Kasimoglu 2013).

Perceived barriers (3). Research on the influence of perceived barriers on EIs is notably underdeveloped. The three papers in this theme are very general, finding that lack of capital, lack of skills and operational problems contribute towards reducing the EI of respondents (e.g., Choo and Wong 2006).

\subsubsection{Discussion}

Drawing on suggestions by Krueger $(2007,2009)$, research on EI could make significant progress by striving to improve the understanding of which deep assumptions lie beneath intentions (Hayton and Cholakova 2012). Assessing the role and the importance of mental 
prototypes, cognitive scripts, mental schemas and maps may shed light on the formation of EIs and the process leading from intention to behavior (Prabhu et al. 2012; Shinnar et al. 2012). These concepts will help to bring about a better understanding of how human decision-making occurs via automatic processing (Krueger and Day 2010).

Cross-fertilization between these themes would be of major interest. In this respect, research could focus on identifying the different barriers that may be deterring the intention-action link for women and men. Similarly, the specific subsamples may perceive different barriers, and the personality and background variables affecting their intentions may differ. Thus, these two less developed themes in this category probably deserve further attention, not only on their own, but also in combination with the remaining themes in this group.

\subsection{Main themes in the entrepreneurial education and entrepreneurial intention category}

These papers either analyze the characteristics of the participants (notably their intentions), compare different programs, or develop program proposals. The vast majority of works focus on the first topic, but with different levels of rigor. Thus, we have further separated this first topic into three themes: the characteristics of the participants (papers using samples of students who have undertaken an entrepreneurship education program - EEP); EEP results (papers reporting a result which is attributed to the program); and EEP evaluation (papers carrying out some kind of meticulous evaluation of the program).

Characteristics of participants (8). In this theme, samples of entrepreneurship education students are studied and their EIs are reported, but with no focus on the program itself (e.g., Bakotic and Kruzic 2010; Tounés 2006). Nonetheless, Ozgen and Minsky (2013) and Leung et al. (2012) use EIs to differentiate those students who decide to participate in entrepreneurial education activities from those who do not.

EEP Results (13). The papers in this theme investigate the EIs of participants in EEP by means of an ex-post measurement. They typically find that the respondents exhibit a high intention level and attribute this result to the program (Shahidi 2012). Two of these studies use GEM data to assess the relationship between having participated in an EEP and stating an EI (e.g., Farashah 2013). Some papers compare students who have/ have not participated in an EEP (e.g., Pihie and Bagheri 2009) and find participants to exhibit higher intention. Notwithstanding, since no pre-course measure is taken, self-selection bias may be present. There is one long-term study (Degeorge and Fayolle 2008) assessing the stability of intentions up to 7 years after participation in the EEP. Finally, Pittaway and Cope's (2007) literature review finds a generally positive relationship.

EEP Evaluation (30). These papers focus on a more rigorous evaluation of specific programs and strive to ascertain whether they are effective in increasing the EI of their participants. The methodologies used vary from the study of a compulsory course (e.g., von Graevenitz et al. 2010), to the inclusion of a control group (e.g., Sanchez 2013), or the use of pre- and postmeasures (e.g., Fayolle et al. 2006; Souitaris et al. 2007). The results generally support the positive effect of EEP on EIs (Solesvik 2013), although prior exposure to entrepreneurship modifies this effect (Fayolle and Gailly 2009). Yet Oosterbeek et al. (2010) find a negative relationship. In this sense, von Graevenitz et al. (2010) consider it beneficial that the general intention level decreases as a result of the realistic information received. More recently, some 
literature reviews on this theme have found numerous methodological weaknesses and called for analyses of a more precise nature (Lorz et al. 2013; Rideout and Gray 2013).

Comparisons (6). The papers in this theme focus on comparing different groups of participants. The diversity in the origin of these participants is wide, such as countries (e.g., Franke and Luthje 2004), regions in a country (Packham et al. 2010) or schools in a single location (Wang and Verzat 2011). Overall, they tend to find differences that are attributed to factors external to the EEP.

Program proposal (11). A number of content and pedagogical-method proposals are made by these papers to improve EEP. Some papers suggest the use of methods that are more practical and experienced-based in general (e.g., Haase and Lautenschlager 2011; Liñán et al. 2011a). Others, in turn, focus on suggestions of a more specific nature, such as modes of thinking and risk perceptions (Barbosa et al. 2008), sense of success/failure (Oser and Volery 2012), or even metacognitive dimensions (Urban 2012). Although all these proposals are not necessarily applicable to every initiative, they offer interesting insights into how to improve/expand existing EEPs.

\subsubsection{Discussion}

The contributions in this category suggest that entrepreneurship education needs to apply differentiated teaching techniques and contents to achieve its full potential. Hitherto, empirical research results have revealed significant differences in terms of attitudes and intention levels of those students who take part in EEPs and those who do not. However, whether and how there can be a generalization of these results to various settings remains pending (Zhao et al. 2005). Furthermore, according to Fayolle and Gailly (2013), little knowledge exists regarding the potential causal link between some educational variables (participant selection and past entrepreneurial exposure, course contents, pedagogical methods, teachers' professional profiles, available resources, etc.) and the impact of EEPs on the antecedents of intention and/or behavior. Research could also address issues relating to the reciprocal relationships between students' EIs, the quality of their entrepreneurial learning, and the development of their entrepreneurial competences in educational settings (Martin et al. 2013).

Another area of research is the comparison of different programs using stricter evaluation methods. This may serve to derive program proposals of a more detailed nature to enhance the existing initiatives. More generally, the authors encourage scholars to conduct studies with a high standard of methodological rigor. Of particular importance to such studies is to have a treatment group (students who receive entrepreneurship education) and a control group (students who do not receive entrepreneurship education). Consideration of randomized assignments to treatment and control groups is also possible in order to avoid sampling biases. Finally, studies should measure relevant variables at both pre- and post-intervention (Fayolle and Gailly 2013; Martin et al. 2013).

\subsection{Main themes in the role of context and institutions category}

The papers in this category have in common their special consideration of the environment(s) and institutions. Two predominant themes clearly emerge: those applying intention models across different cultures, and those focusing on the influence of institutional variables. 
Additionally, the case of entrepreneurs coming from specific cultural backgrounds is also analyzed. Finally, there is one paper that could be classified under the ecological approach.

Cross-cultural studies (25). The variability in the formation of EIs across countries is the main theme here. There is, however, a clear evolution in these studies. Thus, in the first part of the period, two-country samples were common (e.g., De Pillis and Reardon 2007; Kristiansen and Indarti 2004; Veciana et al. 2005). In contrast, since 2010, much wider samples have started to be used, coming from six (Moriano et al. 2012), seven (Davey et al. 2011), twelve (Engle et al. 2010) or even thirteen countries (Iakovleva et al. 2011). There are two studies using GEM data (Hessels et al. 2011; Walker et al. 2013) which confirm the applicability of EI models across countries, although with some variations in the relative influence of each motivational antecedent.

Institutional variables (40). Institutions are "the rules of the game in a society" (North 1990) and shape human interaction. In this theme, various types of institutions are considered: universities (e.g., Turker and Selcuk 2009), social networks (e.g., Zafar et al. 2012), regional context (e.g., Kibler 2013), the media representation of entrepreneurs (Radu and Redien-Collot 2008) or culture (e.g., Schlaegel et al. 2013). The results suggest that EI is higher when the institutions are more favorable (Liñán et al. 2011b). Formal institutions are obviously important, but informal institutions seem to be equally or even more influential (Engle et al. 2011). In this regard, cultural variations within a single country are found to affect the intention levels of its members (Jaén and Liñán 2013).

Cultural backgrounds (6). In this theme, people facing change in a new environment are considered. The typical case is that of immigrants (e.g., Matiz-Bulla and Hormiga 2011). Nevertheless, international (Asian) students in an American university are also analyzed (Li 2007). Yemini and Yeheskel (2011), in turn, compare the EI of Israeli students from different ethnic backgrounds.

Ecological approach (1). The paper by Tang (2008) constitutes a theme of its own. It finds that environmental munificence promotes entrepreneurial alertness which, in turn, increases intention.

\subsubsection{Discussion}

As claimed recently by Welter (2011, p. 165): "There is growing recognition in entrepreneurship research that economic behavior can be better understood within its historical, temporal, institutional, spatial and social context". A strong need exists to examine the heterogeneous aspect of context (Zahra and Wright 2011). Its influence depends on the interaction between several levels of formal and informal institutions. Cross-country analyses have shown the wide applicability of intention models, but much yet needs to be done to fully understand how the context interacts with the person in determining the EI.

Countries are only one sub-dimension of the spatial context. Research could also assess the influence of other sub-dimensions - such as communities, industrial districts and clusters - on EI formation (Liñán et al. 2011b; Jaén and Liñán 2013). More importantly, research could investigate the impact of national, regional, professional and corporate cultures on changes in individual attitudes toward entrepreneurship and EI. The effects of regulative systems and legal 
policies on intentions (Engle et al. 2011) also deserves further investigation. An evaluation could take place of public initiatives, incentives and policies aiming at changing institutions to enable, encourage and facilitate entrepreneurship through their effects on EI, using a pre- and post-intervention research design. This evaluation could contribute to strengthening the link between entrepreneurship research and public policy (Zahra and Wright 2011).

\subsection{Main themes in the Intention-behavior link and entrepreneurial process category}

Two clearly different themes emerged in this category. These papers either carry out longitudinal studies, or they clearly focus on a process view by investigating the role of certain variables within this process.

Longitudinal studies (24). Interventions that track respondents over time are most useful in the understanding of the entrepreneurial process. The first and most well-known paper in this theme tracked nascent entrepreneurs to test the intention-behavior link (Kolvereid and Isaksen 2006). Kautonen et al. (2013) replicated the study and found full support for the TPB theory. Most interestingly, EI is found to predict entrepreneurship in the very long term - after 18 years (Schoon and Duckworth 2012). Other papers focus on explaining venture growth (e.g., Stenholm 2011). There is also scope in this theme to test alternative theories, such as career decision-making (Hirschi 2013), the intentionality, resources, boundary, and exchange theory (Manolova et al. 2012), or the interaction between people, processes, resources and the environment (Kessler and Frank 2009).

Variables affecting the process (15). In this theme, papers clearly adopt a process view of entrepreneurship, with EI playing a key role. Several of these are theoretical papers (e.g., Doern 2009), literature reviews (e.g., Nabi et al. 2006) or the introduction to a special issue (Nabi and Holden 2008). Some papers focus on specific aspects and their effect on the entrepreneurial stages, such as barriers to growth (Doern 2009) or the decreasing influence of personality traits (Frank et al. 2007). In general, they provide highly interesting insights and open a large number of future research lines.

\subsubsection{Discussion}

The most important research challenges on EI are probably in this area. Although research has found a high level of intention-behavior correlation - from 0.90 to 0.96 (Ajzen et al. 2009) - a meta-analytic review of 185 studies using the theory of planned behavior finds that, on average, behavioral intentions explain $27 \%$ of the variance in behavior (Armitage and Conner 2001). Nevertheless, knowledge of the mechanisms and the temporalities that affect how EIs lead to behaviors is still poor (Hessels et al. 2011; Kautonen et al. 2013; Laspita et al. 2012). In this respect, much remains to be ascertained about the changing effect of different variables throughout the process. The possibilities opened by longitudinal studies are vast, since entrepreneurship is dynamic in essence (Krueger 2009).

Additionally, the authors wish to suggest at least two main and complementary directions for future research examining the intention-behavior link in the field of entrepreneurship. Firstly, researchers could apply the implementation intention theory (Gollwitzer 1999). In this regard, Frese (2009) offers an action theory perspective which is based on the implementation intention theory. In his view, goals, action plans, action knowledge and self-efficacy are necessary to 
perform actions and behaviors. Secondly, the concept of individual commitment to a new venture creation process could be the missing link between intention and behavior in the field of entrepreneurship (Fayolle et al. 2011).

\subsection{New research areas}

Out of the 409 papers in our literature review, we found 17 that would not fit easily into any of the previous five categories. The majority of these papers focus on the intention toward very specific entrepreneurial activities. These papers are relatively more recent than the rest, since they have been published from 2010 onwards. In particular, we have identified two themes that seem to be gaining momentum: social and sustainable entrepreneurship intentions.

Social entrepreneurship intention (7). Social entrepreneurship has recently strongly emerged as a research topic and, correspondingly, the social entrepreneurship intention is also a subject of interest. Thus, Forster and Grichnik (2013) find general support for the TPB model in this case, while Smith and Woodworth (2012) stress the role of education. The remaining papers test the effects of some additional variables, such as empathy (Ayob et al. 2013), or analyze specific subsamples (e.g., Prieto 2011).

Sustainable entrepreneurship intention (4). The papers on this theme largely concentrate on two specific topics: personal values as the explanation for the sustainable entrepreneurship intention (e.g., Avasilcăi and Hutu 2010); and the influence of a sustainable orientation on EIs (e.g., Kuckertz and Wagner 2010).

Others (6). Three of the papers in this final theme analyze the intention to perform some very specific behavior, such as the transgenerational intent in family business leaders (Williams et al. 2013). The remaining three papers focus on the EI as contribution towards explaining variables such as the valuation of opportunities (Gregoire and Shepherd 2012) or the entrepreneurial commitment (Parente and Feola 2013).

It is probably too soon to tell, but we believe that some of these topics may become categories of their own in the future. In this respect, social entrepreneurship intention is undoubtedly the most developed subject. There are very promising possibilities of integrating the previous five categories into any of the topics included in this one.

\section{Discussion and Conclusion}

EI is a consolidated area of research within the field of entrepreneurship. However, as new knowledge emerges, more questions arise that need addressing. The main contribution of this paper lies in the categorization or classification of the vast amount of publications focused on EIs over the period 2004-2013 and the identification of some relevant gaps within each of these classifications. This situation implies that further research is necessary for the advancement of understanding in this area. Our paper is offering the first citation and thematic analyses of research on EI, a more and more popular concept in the field of entrepreneurship. Having identified and worked on several hundred scholarship publications, we are addressing two essential questions: What do we know about EI? And what do we need to know about it? 
Citation analysis is a powerful instrument that distinguishes the most influential papers in a field of research. In this study, the 24 key articles found to be most cited have served to identify the five main topic areas within EIs. They have been used as a framework for the thematic analysis. Nevertheless, the classification of 409 papers has not been an easy task, since the focus of some of these papers lie between different themes. Correspondingly, the proximity between some themes in different category groups is also evident. This is the case of, for instance, additional variables (in group 1) and personality factors (in group 2). In all these cases, the paper's main focus and the principal result achieved have been used as classification criteria in our decisionmaking process.

We are confident that this thematic analysis will be highly useful to any researcher, especially those approaching EIs anew, as it offers them an overview of the different sub-fields in this area. At the same time, we have identified very specific topics of research within each theme, hitherto addressed by only a very few papers. Therefore, these topics constitute explicit or implicit gaps in research that may need addressing. Some of these gaps have been identified in the previous section for each of the different categories, but many others may be found.

In this paper, we identify five main lines of specialization in research within the area of EIs, complemented by a sixth line for new research topics. All of these lines are equally important. However, the first line of research (core model, methodological and theoretical issues) is perhaps a category of its own, as contributions in this specific line may not have an immediate practical applicability, but can set the pace for the development of knowledge in the other categories. We are convinced that a great potential exists for EI research to contribute towards a better understanding of the entrepreneurial decision-making process. This situation will, in turn, allow the designing of education initiatives of a more effective nature, a better understanding of the role of context and institutions, and the evolution over time of the individual entrepreneurial process. As a consequence, our aim in reviewing the literature is for this to serve as encouragement for future research to fill the existing gaps.

Additionally, there remains plenty of room to integrate themes between each category in the future by using various methods, such as experiential research designs. For instance, the themes in the core theory and entrepreneurial process categories could be jointly addressed to identify causal order in the entrepreneurial process (Kessler and Frank 2009). Other relevant questions arise from the integration of the core EI model with the context analysis: Is the model stable, or does it change with the context? If so, in what direction? Similarly, each step in the entrepreneurial process may also be affected by context. What institutions (culture, barriers, support measures, and so forth) affect the intention/behavior link? And what about the movement from starting a venture to expanding it? And the decision to exit?

Following the person/context interaction approach (Shaver and Scott 1991), the personal characteristics of participants are undoubtedly relevant. In this sense, they are considered in the following themes: specific subsamples (group 2), comparisons (group 3), and cultural backgrounds (group 4). Although there may be some overlap between them, the main focus is different in each case. Nevertheless, the analysis of the interaction between personal characteristics and context influence is an area in which major research is still needed.

Evidence of the evolution of the field is provided by the publication, from 2010 onwards, of certain papers that cannot be easily included in any of the five initial categories. A number of these papers focus on the intention to perform very specific types of entrepreneurial activity, 
such as social or sustainable entrepreneurship. They differ from those included in the specific intention theme (group 1) in that these latter papers focus on steps within the general entrepreneurial process. The particularities in the formation of these special-type EIs undoubtedly present an interesting area of research.

At the methodological level, almost all empirical papers use positivist methodologies. The EI field of research currently offers little room and scope for humanistic approaches that see the research as value-based and give central place to human beings, human meaning and human actions. Humanistic approaches can be seen as insightful alternative ways in designing and carrying out research on EI in which more comprehensive and qualitative methods are needed (O'Neill and McGuirk 2014). Finding a better balance and sometimes a relevant mix between positivism and humanism appears to be of primary importance to advance research in the field. In this respect, to attain a better understanding of complex psychological mechanisms leading to intention formation and then turning intention into behavior, it is necessary at a certain point to enter into the black box theory of mind.

Our work also has major implications for all kinds of practitioners. In our findings and suggestions, both entrepreneurs and would-be entrepreneurs can find inspiration, ideas, and ways to reinforce their EIs and turn them into successful behaviors. People who support, in a broad sense, nascent entrepreneurs may identify new ways of interacting with entrepreneurs, and therefore help them to improve their entrepreneurial activities. Policy makers at all levels can find relevant material to rethink and improve their public policies aimed at increasing EIs among people and mainly among the young population. Finally, educators, teachers, and instructors engaged in entrepreneurship courses have the opportunity to nurture their students with the knowledge provided in this paper and to reflect on their own practices, by looking at the suggestions and perspectives which have been developed, mainly (but not solely) around the relationship between EI and entrepreneurship education.

This study is not without limitations, which are associated with the methodology used. First, despite our extensive efforts, the literature search may have failed to capture all EI papers. In particular, we excluded contributions such as chapters in edited books. Second, despite every precaution taken, the researchers recognize their subjectivity regarding the classification of papers. Third, the application of bibliometric methods induces constraints. Since publications need time to show a significant impact, we can only show trends and it remains impossible to predict which papers will be the most influential of the field in the future.

\section{References}

Acedo, F. J., \& Casillas, J. C. (2005). Current paradigms in the international management field: An author co-citation analysis. International Business Review, 14(5), 619-639.

Ahmed, I., Nawaz, M.M., Ahmad, Z., Shaukat, M.Z., Usman, A., Wasim-ul-Rehman, \& Ahmed, N. (2010). Determinants of students' entrepreneurial career intentions: Evidence from business graduates. European Journal of Social Sciences, 15(2), 14-22.

Ajzen, I. (1991). The Theory of Planned Behavior. Organizational Behavior and Human Decision Processes, 50(2), 179-211.

Ajzen, I. (2012). The Theory of Planned Behavior. In P. A. M. Van Lange, A. W. Kruglanski \&

E. T. Higgins (Eds.), The handbook of theories of Social Psychology (pp. 438-459).

London: SAGE Publications. 
Ajzen, I., Csasch, C., \& Flood, M. G. (2009). From intentions to behavior: Implementation intention, commitment, and conscientiousness. Journal of Applied Social Psychology, 39(6), 1356-1372.

Ajzen, I., \& Fishbein, M. (1980). Understanding attitudes and predicting social behavior. Englewood Cliffs, NJ: Prentice-Hall.

Armitage, C. J., \& Conner, M. (2001). Efficacy of the theory of planned behavior: a metaanalytic review. British Journal of Social Psychology, 40(4), 471-499.

Armitage, A., \& Keeble-Allen, D. (2008). Undertaking a structured literature review or structuring a literature review: tales from the field. The Electronic Journal of Business Research Methods, 6(2), 103-114.

Avasilcăi, S., \& Hutu, C.A. (2010). Romania: Entrepreneurial values and sustainability. Environmental Engineering and Management Journal, 9(7), 983-992.

Ayob N., Yap C.S., Amat Sapuan D., \& Abdul Rashid, M.Z. (2013). Social entrepreneurial intention among business undergraduates: An emerging economy perspective. Gadjah Mada International Journal of Business, 15(3), 249-267.

Bakotic, D., \& Kruzic, D. (2010). Students' Perceptions and Intentions Towards Entrepreneurship: The Empirical Findings From Croatia. The Business Review, Cambridge, 14(2), 209-215.

Bandura, A. (1982). Self-efficacy mechanism in human agency. American Psychologist, 37, $122-147$.

Bandura, A. (1997). Self-efficacy: The exercise of control. New York: Freeman.

Barbosa, S.D., Kickul, J., \& Smith, B.R. (2008). The Road Less Intended: Integrating Entrepreneurial Cognition and Risk in Entrepreneurship Education. Journal of Enterprising Culture, 16(4), 411-439.

BarNir, A., Watson, W. E., \& Hutchins, H. M. (2011). Mediation and Moderated Mediation in the Relationship Among Role Models, Self-Efficacy, Entrepreneurial Career Intention, and Gender. Journal of Applied Social Psychology, 41(2), 270-297. doi: 10.1111/j.1559-1816.2010.00713.x

Bergevoet R.H.M., Ondersteijn C.J.M., Saatkamp H.W., Van Woerkum C.M.J., \& Huirne R.B.M. (2004). Entrepreneurial behaviour of Dutch dairy farmers under a milk quota system: Goals, objectives and attitudes. Agricultural Systems, 80(1), 1-21.

Bhandari, N.C. (2012). Relationship between students' gender, their own employment, their parents' employment, and the students' intention for entrepreneurship. Journal of Entrepreneurship Education, 15, 133-144.

Bird, B. (1988). Implementing entrepreneurial ideas: the case for intention. Academy of Management Review, 13(3), 442-453.

Bosma, N., Hessels, J., Schutjens, V., Van Praag, M., \& Verheul, I. (2012). Entrepreneurship and role models. Journal of Economic Psychology, 33(2), 410-424.

Boyd, N. G., \& Vozikis, G. S. (1994). The influence of self-efficacy on the development of entrepreneurial intentions and actions. Entrepreneurship Theory and Practice, 18, 6377.

Brandstätter, H. (2011). Personality aspects of entrepreneurship: A look at five meta-analyses. Personality and Individual Differences, 51(3), 222-230.

Brigham, K.H., De Castro, J.O., \& Shepherd, D.A. (2007). A person-organization fit model of owner-managers' cognitive style and organizational demands. Entrepreneurship Theory and Practice, 31(1), 29-51.

Carey, T.A., Flanagan, D.J., \& Palmer, T.B. (2010). An examination of university student entrepreneurial intentions by type of venture. Journal of Developmental Entrepreneurship, 15(4), 503-517.

Carr, J. C., \& Sequeira, J. M. (2007). Prior family business exposure as intergenerational influence and entrepreneurial intent: A Theory of Planned Behavior approach. Journal of Business Research, 60(10), 1090-1098.

Carsrud, A. L., \& Brännback, M. (2011). Entrepreneurial motivations: What do we still need to know? Journal of Small Business Management, 49(1), 9-26. 
Casillas, J. C., \& Acedo, F. J. (2007). Evolution of the intellectual structure of family business literature: A bibliometric study of FBR. Family Business Review, 20(2), 141-162.

Choo, S., \& Wong, M. (2006). Entrepreneurial intention: Triggers and barriers to new venture creations in Singapore. Singapore Management Review, 28(2), 47-64.

Cornelius, B., Landström, H., \& Persson, O. (2006). Entrepreneurial Studies: The dynamic research front of a developing Social Science. Entrepreneurship Theory and Practice, 30(3), 375-398. doi: 10.1111/j.1540-6520.2006.00125.x

Covin, J. G., \& Slevin, D. P. (1989). Strategic management of small firms in hostile and benign environments. Strategic Management Journal, 10(1), 75-87.

Dabic M., Daim T., Bayraktaroglu E., Novak I., \& Basic M. (2012). Exploring gender differences in attitudes of university students towards entrepreneurship: An international survey. International Journal of Gender and Entrepreneurship, 4(3), 316336.

Davey, T., Plewa, C., \& Struwig, M. (2011). Entrepreneurship perceptions and career intentions of international students. Education and Training, 53(5), 335-352.

De Clercq D., Honig B., \& Martin B. (2013). The roles of learning orientation and passion for work in the formation of entrepreneurial intention. International Small Business Journal, 31(6), 652-676.

De Pillis, E., \& Reardon, K. K. (2007). The influence of personality traits and persuasive messages on entrepreneurial intention: A cross-cultural comparison. Career Development International, 12(4), 382-396. doi: 10.1108/13620430710756762

Degeorge, J. M., \& Fayolle, A. (2008). Is entrepreneurial intention stable through time? First insights from a sample of French students. International Journal of Entrepreneurship and Small Business, 5(1), 7-27. doi: 10.1504/IJESB.2008.015951.

Devonish, D., Alleyne, P., Charles-Soverall, W., Marshall, A.Y., \& Pounder, P. (2010). Explaining entrepreneurial intentions in the Caribbean. International Journal of Entrepreneurial Behaviour and Research, 16(2), 149-171.

do Paço, A. M. F., Ferreira, J. M., Raposo, M., Rodrigues, R. G., \& Dinis, A. (2011). Behaviours and entrepreneurial intention: Empirical findings about secondary students. Journal of International Entrepreneurship, 9(1), 20-38. doi: 10.1007/s10843-010-00719

Doern, R. (2009). Investigating Barriers to SME Growth and Development in Transition Environments A Critique and Suggestions for Developing the Methodology. International Small Business Journal, 27(3), 275-305.

Douglas, E.J. (2013). Reconstructing entrepreneurial intentions to identify predisposition for growth. Journal of Business Venturing, 28(5), 633-651.

Drnovsek, M., \& Erikson, T. (2005). Competing Models of Entrepreneurial Intentions. Economic and Business Review for Central and South - Eastern Europe, 7(1), 55-71.

Engle, R.L., Dimitriadi, N., Gavidia, J.V., Schlaegel, C., Delanoe, S., Alvarado, I., He, X., Buame, S., \& Wolff, B. (2010). Entrepreneurial intent: A twelve-country evaluation of Ajzen's model of planned behavior. International Journal of Entrepreneurial Behaviour and Research, 16(1), 36-58.

Engle, R. L., Schlaegel, C., \& Dimitriadi, N. (2011). Institutions and entrepreneurial intent: A cross-country study. Journal of Developmental Entrepreneurship, 16(02), 227-250. doi:10.1142/S1084946711001811

Farashah, A.D. (2013). The process of impact of entrepreneurship education and training on entrepreneurship perception and intention: Study of educational system of Iran. Education and Training, 55(8/9), 868-885.

Fayolle, A., Basso, O., \& Tornikoski, E. T. (2011). Entrepreneurial commitment and new venture creation: a conceptual exploration. In K. Hindle \& K. Klyver (Eds.), Handbook of research on new venture creation (pp. 160-182). Cheltenham (UK): Edward Elgar Publishing.

Fayolle, A., \& Gailly, B. (2009). Évaluation d'une formation en entrepreneuriat: Prédispositions et impact sur l'intention d'entreprendre. Management, 12(3), 175-203. 
Fayolle, A., \& Gailly, B. (2013). The impact of entrepreneurship education on entrepreneurial attitudes and intention: Hysteresis and persistence. Journal of Small Business Management, 53(1), 75-93 (2015).

Fayolle, A., Gailly, B., \& Lassas-Clerc, N. (2006). Assessing the impact of entrepreneurship education programmes: A new methodology. Journal of European Industrial Training, 30(9), 701-720.

Fayolle, A., \& Liñán, F. (2014). The future of research on entrepreneurial intentions. Journal of Business Research, 67(5), 663-666.

Fini, R., Grimaldi, R., Marzocchi, G. L., \& Sobrero, M. (2012). The determinants of corporate entrepreneurial intention within small and newly established firms. Entrepreneurship Theory and Practice, 36(2), 387-414. doi: 10.1111/j.1540-6520.2010.00411.x

Fitzsimmons, J. R., \& Douglas, E. J. (2011). Interaction between feasibility and desirability in the formation of entrepreneurial intentions. Journal of Business Venturing, 26(4), 431440. doi: 10.1016/j.jbusvent.2010.01.001

Forster F., \& Grichnik D. (2013). Social Entrepreneurial Intention Formation of Corporate Volunteers. Journal of Social Entrepreneurship, 4(2), 153-181.

Frank, H., Lueger, M., \& Korunka, C. (2007). The significance of personality in business startup intentions, start-up realization and business success. Entrepreneurship and Regional Development, 19(3), 227-251.

Franke N., \& Luthje C. (2004). Entrepreneurial intentions of business students - A benchmarking study. International Journal of Innovation and Technology Management, l(3), 269-288.

Frese, M. (2009). Toward a psychology of entrepreneurship - An action theory perspective. Foundations and Trends in Entrepreneurship, 5(6), 437-496.

Gartner, W.B. (2010). A new path to the waterfall: A narrative on a use of entrepreneurial narrative. International Small Business Journal, 28(1), 6-19.

Gird, A., \& Bagraim, J.J. (2008). The theory of planned behaviour as predictor of entrepreneurial intent amongst final-year university students. South African Journal of Psychology, 38(4), 711-724.

Gollwitzer, P. M. (1999). Implementation intentions - Strong effects of simple plans. American Psychologist, 54(7), 493-503.

Gregoire D.A., \& Shepherd D.A. (2012). Technology-market combinations and the identification of entrepreneurial opportunities: An investigation of the opportunityindividual nexus. Academy of Management Journal, 55(4), 753-785

Guerrero, M., Rialp, J., \& Urbano, D. (2008). The impact of desirability and feasibility on entrepreneurial intentions: A structural equation model. International Entrepreneurship and Management Journal, 4(1), 35-50.

Gundolf, K., \& Filser, M. (2013). Management research and religion: a citation analysis. Journal of Business Ethics, 112(1), 177-185.

Gupta, V.K., Turban, D.B., \& Bhawe, N.M. (2008). The Effect of Gender Stereotype Activation on Entrepreneurial Intentions. Journal of Applied Psychology, 93(5), 1053-1061.

Gupta, V.K. , Turban, D.B., Wasti, S.A., \& Sikdar, A. (2009). The role of gender stereotypes in perceptions of entrepreneurs and intentions to become an entrepreneur. Entrepreneurship: Theory and Practice, 33(2), 397-417.

Haase, H., \& Lautenschlager, A. (2011). The 'Teachability Dilemma' of entrepreneurship. International Entrepreneurship and Management Journal, 7(2), 145-162.

Hadjimanolis, A., \& Poutziouris, P. (2011). Family business background, perceptions of barriers, and entrepreneurial intentions in Cyprus. International Journal of Entrepreneurial Venturing, 3(2), 168-182.

Haus I., Steinmetz H., Isidor R., \& Kabst R. (2013). Gender effects on entrepreneurial intention: A meta-analytical structural equation model. International Journal of Gender and Entrepreneurship, 5(2), 130-156.

Hayton, J. C., \& Cholakova, M. (2012). The role of affect in the creation and intentional pursuit of entrepreneurial ideas. Entrepreneurship Theory and Practice, 36(1), 41-68. 
Hechavarria, D.M., Renko, M., \& Matthews, C.H. (2012). The nascent entrepreneurship hub: goals, entrepreneurial self-efficacy and start-up outcomes. Small Business Economics, 39(3), 685-701.

Hessels, J., Grilo, I., Thurik, R., \& Zwan, P. (2011). Entrepreneurial exit and entrepreneurial engagement. Journal of Evolutionary Economics, 21(3), 447-471. doi: 10.1007/s00191010-0190-4.

Hirschi A. (2013). Career Decision Making, Stability, and Actualization of Career Intentions: The Case of Entrepreneurial Intentions. Journal of Career Assessment, 21(4), 555-571.

Hmieleski, K.M., \& Corbett, A.C. (2006). Proclivity for improvisation as a predictor of entrepreneurial intentions. Journal of Small Business Management, 44(1), pp. 45-63.

Iakovleva, T., Kolvereid, L., \& Stephan, U. (2011). Entrepreneurial intentions in developing and developed countries. Education and Training, 53(5), 353-370.

Jaén, I., \& Liñán, F. (2013). Work values in a changing economic environment: The role of entrepreneurial capital. International Journal of Manpower, 34(8), 939-960.

Jakopec A., Krecar I.M., \& Susanj Z. (2013). Predictors of entrepreneurial intentions of students of economics. Studia Psychologica, 55(4), 289-297.

Jones, M.V., Coviello N., \& Tang, Y.K. (2011). International Entrepreneurship research (19892009): A domain ontology and thematic analysis Journal of Business Venturing, 26(4) 632-659

Kahneman, D., \& Tversky, A. (1979). Prospect Theory: An analysis of decision under risk. Econometrica, 47(2), 263-291.

Kautonen, T., Van Gelderen, M., \& Tornikoski, E. T. (2013). Predicting entrepreneurial behaviour: A test of the theory of planned behaviour. Applied Economics, 45(6), 697707. doi: http://dx.doi.org/10.1080/00036846.2011.610750

Kessler, A., \& Frank, H. (2009). Nascent entrepreneurship in a longitudinal perspective: The impact of person, environment, resources and the founding process on the decision to start business activities. International Small Business Journal, 27(6), 720-742. doi: $10.1177 / 0266242609344363$

Kibler E. (2013). Formation of entrepreneurial intentions in a regional context. Entrepreneurship and Regional Development, 25(3/4), 293-323.

Kickul, J., Gundry, L.K., Barbosa, S.D., \& Simms, S. (2010). One style does not fit all: The role of cognitive style in entrepreneurship education. International Journal of Entrepreneurship and Small Business, 9(1), pp. 36-57.

Kolvereid, L. (1996a). Organizational employment versus self-employment: Reasons for career intentions. Entrepreneurship Theory and Practice, 20(3), 23-31.

Kolvereid, L. (1996b). Prediction of employment status choice intentions. Entrepreneurship Theory and Practice, 21(1), 47-57.

Kolvereid, L., \& Isaksen, E. (2006). New business start-up and subsequent entry into selfemployment. Journal of Business Venturing, 21(6), 866-885.

Kozan, M.K., Öksoy, D., \& Özsoy, O. (2006). Growth plans of small businesses in Turkey: Individual and environmental influences. Journal of Small Business Management, 44(1), 114-129.

Kraus, S., Filser, M., O'Dwyer, M., \& Shaw, E. (2014). Social entrepreneurship: an exploratory citation analysis. Review of Managerial Science, 8(2), 275-292.

Kraus, S., Rigtering, J. C., Hughes, M., \& Hosman, V. (2012). Entrepreneurial orientation and the business performance of SMEs: a quantitative study from the Netherlands. Review of Managerial Science, 6(2), 161-182.

Kristiansen, S., \& Indarti, N. (2004). Entrepreneurial Intention among Indonesian and Norwegian Students. Journal of Enterprising Culture, 12(1), 55-78.

Krueger, N. F. (2007). What lies beneath? The experiential essence of entrepreneurial thinking. Entrepreneurship Theory and Practice, 31(1), 123-138.

Krueger, N. F. (2009). Entrepreneurial intentions are dead: Long live entrepreneurial intentions. In A. L. Carsrud \& M. Brannback (Eds.), Understanding the entrepreneurial mind (pp. 51-72). New York: Springer. 
Krueger, N. F., \& Brazeal, D. V. (1994). Entrepreneurial potential and potential entrepreneurs. Entrepreneurship Theory and Practice, 19(3), 91-104.

Krueger, N. F., \& Carsrud, A. L. (1993). Entrepreneurial intentions: Applying the theory of planned behavior. Entrepreneurship and Regional Development, 5(4), 315-330.

Krueger, N. F., \& Day, M. (2010). Looking forward, looking backward: From entrepreneurial cognition to neuroentrepreneurship. In Z. J. Acs \& D. B. Audretsch (Eds.), Handbook of entrepreneurship research. An interdisciplinary survey and introduction (2nd ed., pp. 321-358). New York: Springer.

Krueger, N. F., Reilly, M. D., \& Carsrud, A. L. (2000). Competing models of entrepreneurial intentions. Journal of Business Venturing, 15(5-6), 411-432.

Kuckertz, A., \& Wagner, M. (2010). The influence of sustainability orientation on entrepreneurial intentions - Investigating the role of business experience. Journal of Business Venturing, 25(5), 524-539.

Lanero, A., Vázquez, J.L., Gutiérrez, P., \& García, M.P. (2011). The impact of entrepreneurship education in European universities: An intention-based approach analyzed in the Spanish area. International Review on Public and Nonprofit Marketing, 8(2), 111-130.

Laspita, S., Breugst, N., Heblich, S., \& Patzelt, H. (2012). Intergenerational transmission of entrepreneurial intentions. Journal of Business Venturing, 27(4), 414-435. doi: http://dx.doi.org/10.1016/j.jbusvent.2011.11.006

Lee S.H., \& Wong P.K. (2004). An exploratory study of technopreneurial intentions: A career anchor perspective. Journal of Business Venturing, 19(1), 7-28.

Leung, K.-Y., Lo, C.-T., Sun, H., \& Wong, K.-F. (2012). Factors influencing engineering students' intention to participate in on-campus entrepreneurial activities. Journal of Entrepreneurship Education, 15, 1-20.

Li, W. (2007). Ethnic Entrepreneurship: Studying Chinese and Indian Students in the United States. Journal of Developmental Entrepreneurship, 12(4), 449-466.

Liñán, F., \& Chen, Y. W. (2009). Development and cross-cultural application of a specific instrument to measure entrepreneurial intentions. Entrepreneurship Theory and Practice, 33(3), 593-617.

Liñán, F., Rodríguez-Cohard, J.C., \& Rueda-Cantuche, J.M. (2011a). Factors affecting entrepreneurial intention levels: A role for education. International Entrepreneurship and Management Journal, 7(2), 195-218.

Liñán, F., \& Santos, F.J. (2007). Does social capital affect entrepreneurial intentions? International Advances in Economic Research, 13(4), 443-453.

Liñán, F., Urbano, D., \& Guerrero, M. (2011b). Regional variations in entrepreneurial cognitions: Start-up intentions of university students in Spain. Entrepreneurship and Regional Development, 23(3\&4), 187-215.

Lo, C.M., \& Wang, J.R. (2007). The Entrepreneurial Intention under Environmental Uncertainty. Journal of Accounting, Finance \& Management Strategy, 3(1), 21-43.

Loras J., \& Vizcaino J. (2013). Is technical training an obstacle to entrepreneurship? Management Decision, 51(5), 999-1010.

Lorz, M., Mueller, S., \& Volery, T. (2013). Entrepreneurship Education: A Systematic Review of the Methods in Impact Studies. Journal of Enterprising Culture, 21(2), 123-151.

Lourenço, F., \& Jones, O. (2006). Developing entrepreneurship education: comparing traditional and alternative teaching approaches. International Journal of Entrepreneurship Education, 4(1), 111-140.

Manolova, T.S., Edelman, L.F., Brush, C.G., \& Rotefoss, B. (2012). Properties of emerging organizations: Empirical evidence from Norway. Small Business Economics, 39(3), 763-781.

Marques C.S., Ferreira J.J., Gomes D.N., \& Rodrigues R.G. (2012). Entrepreneurship education: How psychological, demographic and behavioural factors predict the entrepreneurial intention. Education and Training, 54(8), 657-672.

Martin, B. C., McNally, J. J., \& Kay, M. J. (2013). Examining the formation of human capital in entrepreneurship: A meta-analysis of entrepreneurship education outcomes. Journal of 
Business Venturing, 28(2), 211-224. doi: http://dx.doi.org/10.1016/j.jbusvent.2012.03.002

Mathieu C., \& St-Jean T. (2013). Entrepreneurial personality: The role of narcissism. Personality and Individual Differences, 55(5), 527-531.

Matiz-Bulla, F.J., \& Hormiga, E. (2011). Highly-skilled Colombian immigrants in Spain. Education \& Training, 53(5), 448-461.

McGee, J.E., Peterson, M., Mueller, S.L., \& Sequeira, J.M. (2009). Entrepreneurial selfefficacy: Refining the measure. Entrepreneurship: Theory and Practice, 33(4), 965988.

Moriano, J. A., Gorgievski, M., Laguna, M., Stephan, U., \& Zarafshani, K. (2012). A crosscultural approach to understanding entrepreneurial intention. Journal of Career Development, 39(2), 162-185. doi: 10.1177/0894845310384481.

Nabi, G., \& Holden, R. (2008). Graduate entrepreneurship: Intentions, education and training. Education and Training, 50(7), 545-551.

Nabi, G., Holden, R., \& Walmsley, A. (2006). Graduate career-making and business start-up: A literature review. Education and Training, 48(5), 373-385.

Nabi G., \& Linan F. (2013). Considering business start-up in recession time: The role of risk perception and economic context in shaping the entrepreneurial intent. International Journal of Entrepreneurial Behaviour and Research, 19(6), 633-655.

Nasurdin, A.M., Ahmad, N.H., \& Lin, C.E. (2009). Examining a model of entrepreneurial intention among Malaysians using SEM procedure. European Journal of Scientific Research, 33(2), 365-373.

North, D. C. (1990). Institutions, institutional change and economic performance. Cambridge University Press.

O’Neill, P., \& McGuirk, P. (2014). Qualitative methods in socio-spatial research. In R. Stimson (Ed.), Handbook of Research Methods and Applications in Spatially Integrated Social Science (pp. 177-191). Cheltenham (UK): Edward Elgar.

Oosterbeek, H., van Praag, M., \& Ijsselstein, A. (2010). The impact of entrepreneurship education on entrepreneurship skills and motivation. European Economic Review, 54(3), 442-454.

Oser F., \& Volery T. (2012). «Sense of failure» and «sense of success» among entrepreneurs: The identification and promotion of neglected twin entrepreneurial competencies. Empirical Research in Vocational Education and Training, 4(1), 27-44.

Ozgen E., \& Minsky B.D. (2013). Why some college students engage in entrepreneurial activities while others do not. Journal of Entrepreneurship Education, 16, 45-58.

Packham, G., Jones, P., Miller, C., Pickernell, D., \& Thomas, B. (2010). Attitudes towards entrepreneurship education: A comparative analysis. Education and Training, 52(8), 568-586.

Parente R., \& Feola R. (2013). Entrepreneurial intent and entrepreneurial commitment of young researchers. International Journal of Technology Management and Sustainable Development, 12(2), 155-166.

Pihie, Z.A.L. (2009). Entrepreneurship as a career choice: An analysis of entrepreneurial selfefficacy and intentions of university students. European Journal of Social Sciences, 9(2), 338-349.

Pihie, Z.A.L., \& Bagheri, A. (2009). Developing future entrepreneurs: A need to improve science students' entrepreneurial participation. International Journal of Knowledge, Culture and Change Management, 9(2), 45-57.

Pittaway, L., \& Cope, J. (2007). Entrepreneurship education - A systematic review of the evidence. International Small Business Journal, 25(5), 479-510.

Podsakoff, P., MacKenzie, S., Bachrach, D., \& Podsakoff, N. (2005). The influence of management journals in the 1980s and 1990s. Strategic Management Journal 26, 473488.

Prabhu, V. P., McGuire, S. J., Drost, E. A., \& Kwong, K. K. (2012). Proactive personality and entrepreneurial intent: Is entrepreneurial self-efficacy a mediator or moderator? International Journal of Entrepreneurial Behaviour and Research, 18(5), 559-586. 
Prieto, L.C. (2011). The influence of proactive personality on social entrepreneurial intentions among African-American and Hispanic undergraduate students: The moderating role of hope. Academy of Entrepreneurship Journal, 17(2), 77-96.

Quan, X. (2012). Prior experience, social network, and levels of entrepreneurial intentions. Management Research Review, 35(10), 945-957.

Radu, M., \& Loué, C. (2008). Motivational Impact of Role Models as Moderated by "Ideal" vs. "Ought Self-Guides" Identifications. Journal of Enterprising Culture, 16(4), 441-465.

Radu, M., \& Redien-Collot, R. (2008). The social representation of entrepreneurs in the French press: Desirable and feasible models? International Small Business Journal, 26(3), 259298.

Renko, M., Kroeck, K.G., \& Bullough, A. (2012). Expectancy theory and nascent entrepreneurship. Small Business Economics, 39(3), 667-684.

Rideout, E.C., \& Gray, D.O. (2013). Does Entrepreneurship Education Really Work? A Review and Methodological Critique of the Empirical Literature on the Effects of UniversityBased Entrepreneurship Education. Journal of Small Business Management, 51(3), 329351.

Rigtering, J. C., Kraus, S., Eggers, F., \& Jensen, S. H. (2014). A comparative analysis of the entrepreneurial orientation/growth relationship in service firms and manufacturing firms. Service Industries Journal, 34(4), 275-294.

Ryan, G.W., \& Bernard, H.R. (2003). Techniques to identify themes. Field Methods 15(1), 85109.

Saeed R., Nayyab H.H., Rashied H., Lodhi R.N., Musawar S., \& Iqbal A. (2013). Who is the most potential entrepreneur? A case of Pakistan, Middle East Journal of Scientific Research, 17(9), 1307-1315.

Salhi, B., \& Boujelbene, Y. (2013). La formation de l'intention entrepreneuriale des étudiants suivant des programmes en entrepreneuriat. La Revue Gestion et Organisation, 5(1), 4061.

Sanchez J.C. (2013). The impact of an entrepreneurship education program on entrepreneurial competencies and intention. Journal of Small Business Management, 51(3), 447-465.

Sarasvathy, S. D. (2001). Causation and effectuation: Toward a theoretical shift from economic inevitability to entrepreneurial contingency. Academy of Management Review, 26, 243263.

Schlaegel, C., He, X., \& Engle, R.L. (2013). The Direct and Indirect Influences of National Culture on Entrepreneurial Intentions: A Fourteen Nation Study. International Journal of Management, 30(2), 597-609.

Schoon I., \& Duckworth K. (2012). Who becomes an entrepreneur? Early life experiences as predictors of entrepreneurship. Developmental Psychology, 48(6), 1719-1726.

Segal G., Borgia D., \& Schoenfeld J. (2005). The motivation to become an entrepreneur. International Journal of Entrepreneurial Behaviour and Research, 11(1), 42-57.

Shahidi, N. (2012). Les jeunes entrepreneurs nécessitent-ils un accompagnement particulier? Le cas français. Journal of Small Business and Entrepreneurship, 25(1), 57-74.

Shapero, A. (1984). The entrepreneurial event. In C. A. Kent (Ed.), The Environment for entrepreneurship. Lexington, Mass.: Lexington Books.

Shapero, A., \& Sokol, L. (1982). Social dimensions of entrepreneurship. In C. A. Kent, D. L. Sexton \& K. H. Vesper (Eds.), Encyclopedia of entrepreneurship (pp. 72-90). Englewood Cliffs (NJ): Prentice Hall.

Shaver, K. G., \& Scott, L. R. (1991). Person, process, choice: The psychology of new venture creation. Entrepreneurship Theory and Practice, 16(2), 23-45.

Shinnar, R. S., Giacomin, O., \& Janssen, F. (2012). Entrepreneurial perceptions and intentions: The role of gender and culture. Entrepreneurship Theory and Practice, 36(3), 465-493. doi: 10.1111/j.1540-6520.2012.00509.x

Shook, C. L., Priem, R. L., \& McGee, J. E. (2003). Venture creation and the enterprising individual: a review and synthesis. Journal of Management, 29(3), 379-399. 
Smith, I.H., \& Woodworth, W.P. (2012). Developing Social Entrepreneurs and Social Innovators: A Social Identity and Self-Efficacy Approach. Academy of Management Learning \& Education, 11(3), 390-407.

Solesvik M.Z. (2013). Entrepreneurial motivations and intentions: Investigating the role of education major. Education and Training, 55(3), 253-271.

Solesvik, M.Z., Westhead, P., Kolvereid, L., \& Matlay, H. (2012). Student intentions to become self-employed: The Ukrainian context. Journal of Small Business and Enterprise Development, 19(3), 441-460.

Sommer, L., \& Haug, M. (2011). Intention as a cognitive antecedent to international entrepreneurship-understanding the moderating roles of knowledge and experience. International Entrepreneurship and Management Journal, 7(1), 111-142.

Stenholm, P. (2011). Innovative Behavior as a Moderator of Growth Intentions. Journal of Small Business Management, 49(2), 233-251.

Strobl, A., Kronenberg, C., \& Peters, M. (2012). Entrepreneurial attitudes and intentions: Assessing gender specific differences. International Journal of Entrepreneurship and Small Business, 15(4), 452-468.

Souitaris, V., Zerbinati, S., \& Al-Laham, A. (2007). Do entrepreneurship programmes raise entrepreneurial intention of science and engineering students? The effect of learning, inspiration and resources. Journal of Business Venturing, 22(4), 566-591.

Sweida G.L., \& Reichard R.J. (2013). Gender stereotyping effects on entrepreneurial selfefficacy and high-growth entrepreneurial intention. Journal of Small Business and Enterprise Development, 20(2), 296-313.

Tang, J. (2008). Environmental munificence for entrepreneurs: Entrepreneurial alertness and commitment. International Journal of Entrepreneurial Behaviour and Research, 14(3), $128-151$.

Tegtmeier, S. (2012). Empirical Implications for Promoting Students' Entrepreneurial Intentions. Journal of Enterprising Culture, 20(2), 151-169.

Thompson, E.R. (2009). Individual entrepreneurial intent: Construct clarification and development of an internationally reliable metric. Entrepreneurship: Theory and Practice, 33(3), pp. 669-694.

Thorpe, R., Holt, R., MacPherson, A., \& Pittaway, L. (2005). Using knowledge within small and medium-sized firms: a systematic review of the evidence. International Journal of Management Reviews 7(4), 257-281.

Tornikoski, E.T., \& Kautonen, T. (2009). Enterprise as sunset career? Entrepreneurial intentions in the ageing population. International. Journal of Entrepreneurship and Small Business, 8(2), 278-291.

Tounés, A. (2006). L'intention entrepreneuriale des étudiants: le cas français. La Revue des Sciences de Gestion : Direction et Gestion, 41(219), 57-65.

Tranfield, D., Denyer, D., \& Smart, P. (2003). Towards a methodology for developing evidence-informed management knowledge by means of systematic review. British Journal of Management, 14(3), 207-222.

Tumasjan, A., Welpe, I., \& Spörrle, M. (2013). Easy Now, Desirable Later: The Moderating Role of Temporal Distance in Opportunity Evaluation and Exploitation. Entrepreneurship: Theory and Practice, 37(4), 859-888.

Turker, D., \& Selcuk, S.S. (2009). Which factors affect entrepreneurial intention of university students? Journal of European Industrial Training, 33(2), 142-159.

Urban, B. (2012). Applying a Metacognitive Perspective to Entrepreneurship: Empirical Evidence on the Influence of Metacognitive Dimensions on Entrepreneurial Intentions. Journal of Enterprising Culture, 20(2), 203-225.

Uygun, R., \& Kasimoglu, M. (2013). The Emergence of Entrepreneurial Intentions in Indigenous Entrepreneurs: The Role of Personal Background on the Antecedents of Intentions. International Journal of Business and Management, 8(5), 24-40.

Van Gelderen, M., Brand, M., Van Praag, M., Bodewes, W., Poutsma, E., \& Van Gils, A. (2008). Explaining entrepreneurial intentions by means of the theory of planned behaviour. Career Development International, 13(6), pp. 538-559. 
Veciana, J.M., Aponte, M., \& Urbano, D. (2005). University Students' Attitudes Towards Entrepreneurship: A Two Countries Comparison International Entrepreneurship and Management Journal, 1(2), 165-182.

von Graevenitz, G., Harhoff, D., \& Weber, R. (2010). The effects of entrepreneurship education. Journal of Economic Behavior and Organization, 76(1), 90-112.

Walker J.K., Jeger M., \& Kopecki D. (2013). The Role of Perceived Abilities, Subjective Norm and Intentions in Entrepreneurial Activity. Journal of Entrepreneurship, 22(2), 181202.

Wang, Y., \& Verzat, C. (2011). Generalist or specific studies for engineering entrepreneurs?: Comparison of French engineering students' trajectories in two different curricula. Journal of Small Business and Enterprise Development, 18(2), 366-383.

Watchravesringkan K.T., Hodges N.N., Yurchisin J., Hegland J., Karpova E., Marcketti S., \& Yan R.-N. (2013). Modeling Entrepreneurial Career Intentions among Undergraduates: An Examination of the Moderating Role of Entrepreneurial Knowledge and Skills. Family and Consumer Sciences Research Journal, 41(3), 325-342.

Welter, F. (2011). Contextualizing entrepreneurship - Conceptual challenges and ways forward. Entrepreneurship Theory and Practice, 35(1), 165-184.

Werner, A., Gast, J., \& Kraus, S. (2014). The effect of working time preferences and fair wage perceptions on entrepreneurial intentions among employees. Small Business Economics, 43(1), 137-160, doi: 10.1007/s11187-013-9528-2.

Williams, D.W., Zorn, M.L., Crook, T.R., \& Combs, J.G. (2013). Passing the Torch: Factors Influencing Transgenerational Intent in Family Firms. Family Relations, 62(3), 415428.

Wilson, F., Kickul, J., \& Marlino, D. (2007). Gender, entrepreneurial self-efficacy, and entrepreneurial career intentions: Implications for entrepreneurship education. Entrepreneurship: Theory and Practice, 31(3), 387-406.

$\mathrm{Wu}, \mathrm{S} ., \& \mathrm{Wu}, \mathrm{L}$. (2008). The impact of higher education on entrepreneurial intentions of university students in China. Journal of Small Business and Enterprise Development, 15(4), 752-774.

Xi, J. M., Kraus, S., Filser, M., \& Kellermanns, F. W. (2013). Mapping the field of family business research: past trends and future directions. International Entrepreneurship and Management Journal, 1-20, DOI: 10.1007/s11365-013-0286-z.

Xiao L., Larson M., \& North D. (2013). Influence of entrepreneurial teams on the growth orientation of earlystage high-tech SMEs in China: Multiple measures of performance, International Journal of Entrepreneurship and Innovation, 14(1), pp. 29-38.

Yemini, M., \& Yeheskel, O. (2011). Not born here-evaluation of the country of origin effect on the entrepreneurial intentions of Israeli engineering students. International Journal of Learning, 17(10), 329-342.

Zafar, M.J., Yasin, G., \& Ijaz, M. (2012). Social Networking A Source for Developing Entrepreneurial Intentions among Entrepreneurs: A Case of Multan. Asian Economic and Financial Review, 2(8), 1072-1084.

Zahra, S. A., \& Wright, M. (2011). Entrepreneurship's next act. Academy of Management Perspectives, 25(4), 67.83.

Zampetakis, L.A., Gotsi, M., Andriopoulos, C., \& Moustakis, V. (2011). Creativity and Entrepreneurial Intention in Young People: Empirical Insights from Business School Students. International Journal of Entrepreneurship and Innovation, 12(3), pp. 189199.

Zampetakis, L.A., Kafetsios, K., Bouranta, N., Dewett, T., \& Moustakis, V.S. (2009). On the relationship between emotional intelligence and entrepreneurial attitudes and intentions. International Journal of Entrepreneurial Behaviour and Research, 15(6), 595-618.

Zellweger, T., Sieger, P., \& Halter, F. (2011). Should I stay or should I go? Career choice intentions of students with family business background. Journal of Business Venturing, 26(5), 521-536. doi: 10.1016/j.jbusvent.2010.04.001 
Zhao, H., Hills, G.E., \& Siebert, S.E. (2005). The mediating role of self-efficacy in the development of entrepreneurial intentions. Journal of Applied Psychology, 90(6), 12651272.

Zhao, H., Seibert, S.E., \& Lumpkin, G.T. (2010). The relationship of personality to entrepreneurial intentions and performance: A meta-analytic review. Journal of Management, 36(2), 381-404. 
Table 1. Most-cited papers (2004-2013)

\begin{tabular}{|c|c|c|c|}
\hline Group category & Paper & Journal $^{\mathrm{a}}$ & Cites \\
\hline \multirow{5}{*}{$\begin{array}{l}\text { Gr.1. Core Entrepreneurial } \\
\text { Intention Model }\end{array}$} & Zhao, Hills \& Seibert (2005) & JAP & 94 \\
\hline & Liñan \& Chen (2009) & ETP & 57 \\
\hline & Hmieleski \& Corbett (2006) & JSBM & 27 \\
\hline & Thompson (2009) & ETP & 24 \\
\hline & van Gelderen et al. (2008) & CDI & 23 \\
\hline \multirow{9}{*}{$\begin{array}{ll}\text { Gr. } \quad 2 . \\
\text { variables }\end{array}$} & Wilson, Kichul \& Marlino (2007) & ETP & 49 \\
\hline & Segal, Borgia \& Schoenfeld (2005) & IJEBR & 26 \\
\hline & Guerrero, Rialp \& Urbano (2008) & IEMJ & 23 \\
\hline & Lee \& Wong (2004) & JBV & 21 \\
\hline & Carr \& Sequeira (2007) & JBR & 19 \\
\hline & Gupta et al. (2009) & ETP & 19 \\
\hline & Liñán \& Santos (2007) & IAER & 17 \\
\hline & Gupta, Turban \& Bhawe (2008) & JAP & 15 \\
\hline & Gird \& Bagraim (2008) & SAJP & 13 \\
\hline \multirow{4}{*}{$\begin{array}{l}\text { Gr. 3. Entrepreneurship } \\
\text { education }\end{array}$} & Souitaris, Zerbinat \& Al-Laham (2007) & JBV & 79 \\
\hline & Fayolle, Gailly \& Lassas-Clerc (2006) & JEIT & 42 \\
\hline & Pittaway \& Cope (2007) & ISBJ & 25 \\
\hline & Frank \& Lüthje (2004) & IJITM & 17 \\
\hline \multirow{4}{*}{$\begin{array}{l}\text { Gr. } \quad 4 . \\
\text { institutions }\end{array}$} & Veciana, Aponte \& Urbano (2005) & IEMJ & 31 \\
\hline & Kristiansen \& Indarti (2004) & JEC & 21 \\
\hline & Depillis \& Reardon (2007) & CDI & 17 \\
\hline & Engle et al. (2010) & IJEBR & 14 \\
\hline \multirow{2}{*}{$\begin{array}{l}\text { Gr. } 5 . \\
\text { process }\end{array}$} & Kolvereid \& Isaksen (2006) & JBV & 49 \\
\hline & Nabi, Holden \& Walmsley (2006) & $E+T$ & 13 \\
\hline
\end{tabular}

${ }^{\text {a }}$ CDI (2 papers): Career Development International; ETP (4): Entrepreneurship Theory \& Practice; E+T: Education + Training; IAER: International Advances in Economic Research; IEMJ (2): International Entrepreneurship \& Management Journal; IJEBR (2): International Journal of Entrepreneurial Behavior and Research; IJITM: International Journal of Innovation and Technology Management; ISBJ: International Small Business Journal; JAP (2): Journal of Applied Psychology; JBR: Journal of Business Research; JBV (3): Journal of Business Venturing; JEC: Journal of Enterprising Culture; JEIT: Journal of European Industrial Training; JSBM: Journal of Small Business Management; SAJP: South African Journal of Psychology 
Table 2. Entrepreneurial intention papers by category

\begin{tabular}{cccccccccccc} 
& 2004 & 2005 & 2006 & 2007 & 2008 & 2009 & 2010 & 2011 & 2012 & 2013 & Total \\
\hline G1 & - & 2 & 3 & 2 & 1 & 8 & 9 & 10 & 16 & 14 & 65 \\
G2 & 4 & 2 & 4 & 6 & 15 & 14 & 14 & 25 & 30 & 34 & 148 \\
G3 & 1 & 1 & 4 & 4 & 4 & 5 & 9 & 12 & 16 & 12 & 68 \\
G4 & 1 & 1 & - & 4 & 4 & 8 & 7 & 18 & 15 & 14 & 72 \\
G5 & - & - & 2 & 5 & 4 & 4 & 3 & 5 & 9 & 7 & 39 \\
G6 & - & - & - & - & - & - & 3 & 2 & 5 & 7 & 17 \\
\hline Total & 6 & 6 & 13 & 21 & 28 & 39 & 45 & 72 & 91 & 88 & 409 \\
\hline
\end{tabular}


Figure 1. Categories of papers from citation analysis

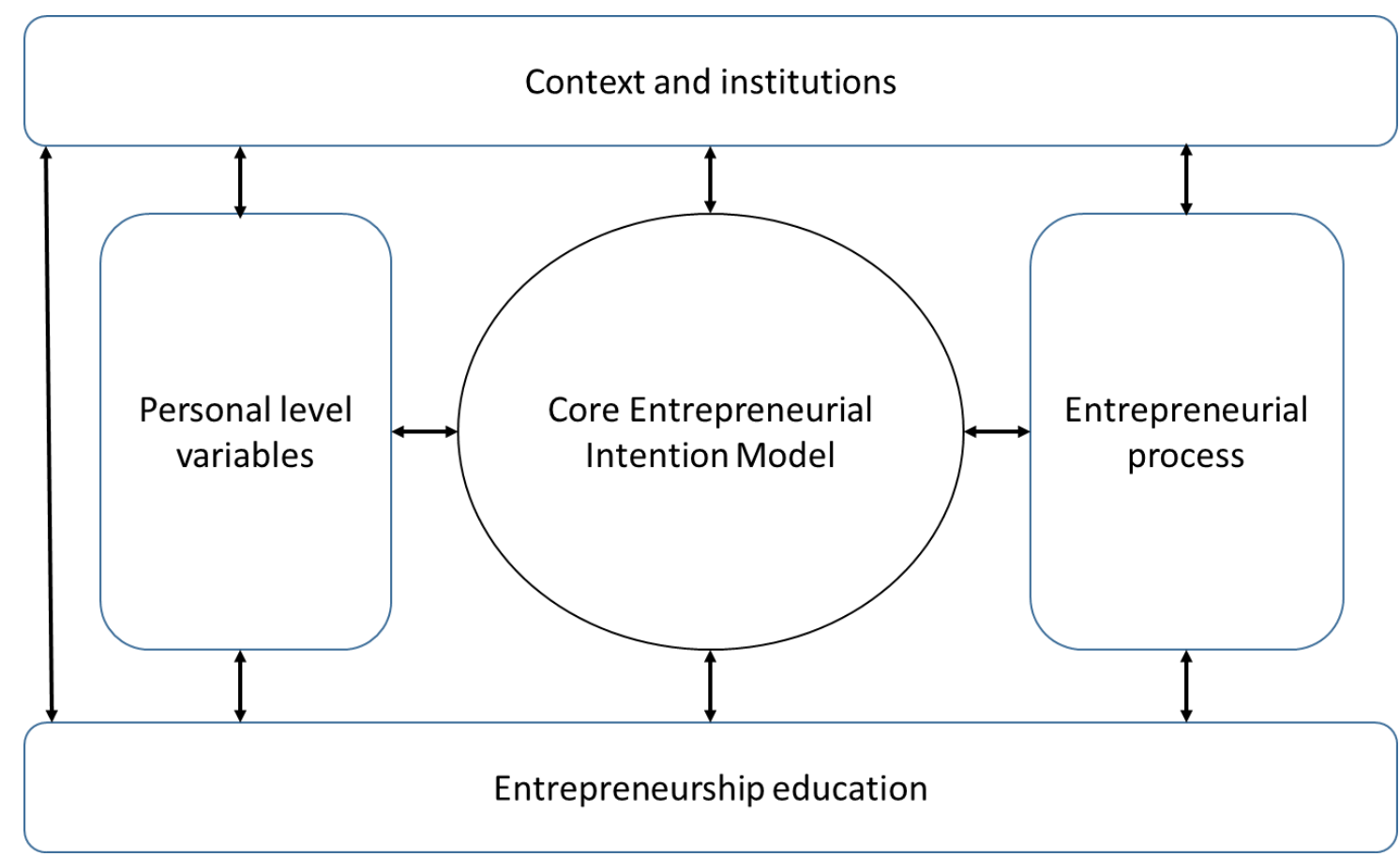


Figure 2. Sub-categories in recent entrepreneurial intention research

\begin{tabular}{|c|c|}
\hline Core Entrepr. intention model (65) & $\begin{array}{l}\text { - General test of the theory (23) } \\
\text { - Specific intentions (18) } \\
\text { - New theoretical framework (9) } \\
\text { - Additional variables (5) } \\
\text { - Configuration of motivational antecedents (7) } \\
\text { - Methodology (3) }\end{array}$ \\
\hline Personal-level variables (148) & $\begin{array}{l}\text { - Background factors (35) } \\
\text { - Personality/psychology factors (72) } \\
\text { - Gender issues (30) } \\
\text { - Specific subsamples (3) } \\
\text { - Perceived barriers (3) }\end{array}$ \\
\hline Entrepreneurship education (68) & $\begin{array}{l}\text { - Characteristics of participants (8) } \\
\text { - EEP Results (13) } \\
\text { - EEP Evaluation (30) } \\
\text { - Comparisons (6) } \\
\text { - Programme proposal (11) }\end{array}$ \\
\hline Context and institutions (72) & $\begin{array}{l}\text { - Cross-cultural studies (25) } \\
\text { - Cultural backgrounds (6) } \\
\text { - Institutional variables (40) } \\
\text { - Ecological approach (1) }\end{array}$ \\
\hline Entrepreneurial process (39) & $\begin{array}{l}\text { - Longitudinal studies (24) } \\
\text { - Variables affecting the process (15) }\end{array}$ \\
\hline New research areas (17) & $\begin{array}{l}\text { - Sustainable entrepreneurship (4) } \\
\text { - Social entrepreneurship (7) } \\
\text { - Others (6) }\end{array}$ \\
\hline
\end{tabular}

